\title{
MIDWIFERY CARE STANDARDS FOR THE FIRST STAGE OF LABOUR
}

\section{Z Railoon and AGW Nolte}

\section{OPSOMMING}

Die herstrikturering van gesondheidsdienste en die klem verksuiwing na omvattende gesond-heidsorg, het dit noodaaklik gemaak vir die formulering van standaarde en kraamsorg om te verseker dat gemeenskapswerwagtinge, etiese en wettige verpligtinge nagekom word

Vandag is die fokus van sorg op gesingesentreerde sorg. Swangerskap is nie meer ' $n$ individuele aangeleentheid maar in gesins aangeleentheid. Die gesin begin om 'n meer aktiewe rol te speel, dus 'n verandering in die houding van gesondheid verskaffers is nodig om hierdie verandering te weeg te bring. Die gesin moel met waardigheid behandel word en op hoogte van sake gehou word om hul kindergehoorte ervaring te versterk.

'n Besknwwende navorsing metode is gebruik om die veranderlikes van sorg tydens die eerste stadium van baring te identifiseer, beskonf en te valideer binne die konteks van wetenskaplike verloskundige sorg.

Die uitslae van die validasie van verpleegsorgstandaarde tydens die eersle sladium van baring is bepaal deur die bepaling van die inhoudsgeldigheidsindeks (CVI) en die slandaard afwyking $(S D)$.

Die aanbevelings dui aan dat herformulering van relevante standaarde en kriteria en die publikasie van die siandaarde van sorg tydens die eerste stadium van baring nodig is vir die gebruik van Vroeduroue. Dit sal dien as riglyne vir die verbetering van die kwaliteit van sorg tydens baring. Vroedvroue moet indiensopleiding ontvang in verband met onvvattende gesondheidsorg en gesingesen-treerdesorg om te verseker dat die klient/gesin se behoefies nagekom word.

\section{INTRODUCTION}

Changes in the social and political structures have brought about changing demands on the delivery of health care. The restructuring of health care under the banner of comprehensive health care has brought about a diversity of lifestyles, traditions, cultures, customs and language barriers which presently cannot be met in totality because of lack of knowledge and understanding of the above-mentioned aspects on the part of health professionals.

Fathers and family members are beginning to take a more active part in child-rearing and pregnancy is becoming a family affair. Families are demanding greater involvement thus enhancing the delivery experience. The birth of a baby is one of life's most meaningful events which preferably should be shared with family members and not strangers. This has lead to a shift from hospital to natural birth settings where the family can be accommodated. The woman has a right to expect safe and competent nursing care and the midwife is ethically and legally bound to provide the best possible nursing care for her client. Parturient couples are demanding greater involvement and decision-making in the method and type of delivery, thus the midwives' dilemma is ensuring that her practice is within the ethical and legal aspects laid down by the $S$.A.Nursing Council as well as satisfying the needs of the parturient and her family. The pressures on the National Health service and changing consumer expectations have made it imperative for mid wives to look critically and analytically at the quality of care being rendered and there is real noed for the formulation of standards in midwifery care to ensure that the Midwife complies with these requirements.

\section{THE RESEARCH PROBLEM}

The questions which thus arise arc

2.1 How can the midwife render quality comprehensive health care to the partunent family during the first stage of labour?

2.2 How can she render mid wifery care based on scientific principles within the ethical and legal framework?

\section{THE AIM OF THE STUDY}

The aim of the study is to formulate valid structure and process standards for improving the quality of care during the first stage of labour.

\section{DEFINITION OF TERMS}

\subsection{QUALITY HEALTH CARE}

Douglas and Bevis (1983:281) base quality health care on the following: "safe", "advanced", "efficient" and "acceptable". The quality of care being rendered can be measured by the quality assurance process which is a process of formulating standards, evaluating performance of current care rendered against set standards and taking remedial action to improve practice. (Jemigan \& Young, 1983:9). Standards serve as a yardstick to measure the quality of care being rendered.

\subsection{NURSING CARE STANDARDS}

Nursing care standards are a descriptive statement of desired quality against which to evaluate nursing care rendered to a patient

\subsection{FIRST STAGE OF LABOUR}

First stage of labour begins with the onset of regular contractions and is complete when the cervix is fully dilated (Jensen \& Bobak, 1985:436)

\section{DESIGN OF THE RESEARCH}

In the formulation of nursing care standards a descriptive design is used to identify, describe and validate the variables of care during the first stage of labour.

\subsection{RESEARCH TECHNIQUE}

The research technique for the formulation of standards consists of the developmental and quantifying phases respectively (Muller, 1990:12).

\subsubsection{The developmental phase}

This phase is based on a conceptual framework of care during the first stage of labour prior to formulating standards. A scientific model of midwifery care is used whereby the practice of mid wifery care during the first stage of labour is evaluated (Wright in Muller, 1990: 12). 


\section{Stage I}

The aim of this stage was to do a literature study of care during the first stage of labour and to define core words.

\section{Stage II}

Concept standards were formulated with reference to the literature study. The concept standards and criteria were listed

- The Midwife.

- Philosophy

- Objoctives.

- Policies and procedures

- The scientific method of nursing.

- Quality care by the midwife during the first stage of labour.

These were then distributed to peer group of experts for cognitive analysis and logical systematization. Background information on the research, instructions for the discussion of the standards, including the meaning of concepts was sent to the sample of experts. The researcher's telephone number was included for possible queries. The group of experts then met for discussion and to make recommendations. The goal of the preparation and discussion phases was to refine the standards and to reinforce the content validity of each individual standard. The necessary changes were brought about according to the recommendations of this advisory group.

\subsubsection{The quantifying phase}

During this phase the statistical validity of the standards was determined (Lynn in Muller. 1990:21).

A four point ordinal Likert scale was used to evaluate the validity of each standard as follows:

1 irrelevant/not applicable to the first stage of labour.

2 indistinct and applicability questionable.

3 applicable but needs reformulation.

4 complete, clear well formulated and highly applicable/realistic to be used as a minimum standard in labour institutions to assure/improve the quality of midwifery care being rendered

These standards were sent to midwives with experience in different spheres of midwifery i.e. academic and clinical, in order to validate each standard. Information regarding the research, instructions for the validation of the standards were sent to the selected sample of experts. The researcher's telephone number was included for possible queries. The validity of each standard was determined by calculating averages and standard deviations.

\subsection{THE POPULATION AND SAMPLE FOR PEER GROUP REVIEW AND VALIDATION OF STANDARDS}

\subsubsection{The target population}

Consisted of experts in different spheres of midwifery namely:

- Midwives rendering care during labour at 3 public hospitals in Johannesburg.

- Midwives studying for their Master's degree in Advanced Midwifery and Neonatology at a university in Johannesburg.

- University lecturers who are experts in formulating standards

\subsubsection{The sample}

Goal directed sampling was used for both phases of validation.

\section{- The developmental phase}

Sisters from the labour ward unit of one of the public hospitals will be consulted in the formulation of standards. Seven midwifery experts were selected to participate in peer group discussion of the standards:

- Two from a university lecturing in Midwifery education.

- One from a nursing college in Midwifery education studying for a Master's degree.

- One from nursing practice with a Honours degree.

- Three from midwifery practice each with more than eleven years clinical experience.

\section{- The quantifying phase}

Practising Midwives from the labour units and midwifery education of the three public hospitals in Johannesburg, Midwifery lecturers from a University and Colleges of Nursing in Johannesburg will be participating A sample of 30 will be selected consisting of:

- Seven experts of the developmental phase.

- Twenty three practising midwives from a University, Colleges and hospitals in Johannesburg.

\subsection{CONTENT VALIDITY}

The content validity was confirmed by the literature study as well as by the experts. Content validity during the quantifying phase was determıned statistically by means of a content validity index. The index is derived from rating of the content relevance of the items on an instrument using a four point ordinal rating scale, in which one indicates an irrelevant item and four an extremely relevant item. Items with an average of between 3.0 or 4.0 are considered valid (Muller, 1990:28)

\subsection{RELIABILITY}

The researcher attempted to control the reliability in the following manner (Muler, 1990:229):

- A structured two-phase procedure was used for the validation of standards;

- clear, structured written instructions were given to participants during both stages;

- during the discussion of the standards the researcher gave each person an equal opportunity to give her point of view on each standard. The group was not dominated by the opinions of one specific person at any stage;

- midwives from the University, Colleges and the three chosen hospitals validated the standards independently during the second stage to avoid direct influence of the researcher on the participants;

- a list of definitions was included to explain some of the terminology used to avoid confusion;

- the anonymity of the participants was assured in order to improve objectivity and honesty in their grading of the standards.

\subsection{RESULTS}

The results will be presented under the followingsections:-@BULLET = The description of the sample.

- The interpretation of the results of the validated standards. This will be done statistically according to the content validity index (CVI) and the standard deviation (SD) level.

- The results of the validation of nursing care standards for the first stage of labour.

\section{RESULTS}

\subsection{Interpretation of the results of validated standards}

During this phase the statistical validity of all the standards were determined (Lynn in Muller, 1990:21). After refining the standards, a four point ordinal Likert scale was used to evaluate the validity of each standard

The content validity is confirmed by the literature, as well as experts in the field of midwifery. The content validity was 
determined statistically during the quantifying phase by means of a content validity index using a four point ordinal Likert rating scale scored as described above. A content validity index of 3.5 was used in this study as the minimum for accepting a standardlcriterium (Muller, 1990 in Nolte, 1990:57). A standard deviation level of 0.5 indicated consensus between the respondents. Items with a standard deviation outside this range require reformulation/ revalidation depending on the scoring of the respondents.

The results of the validity of standards/criteria will be presented as follows: The standard/criteria are stated together. If it was accepted unchanged no result is indicated but if it required reformulation this is indicated in brackets.

6.1.1Results of the validation of nursing care standards for the first stage of labour

\section{A.THE MIDWIFE}

\section{Principłe}

The midwife is one who is appropriately qualified and who continuously updates her knowledge and contributes towards quality midwifery care.

\section{Standard}

The mid wife who renders care during the first stage of labour is qualified and proficient.

\section{Criteria}

- The midwife is registered with the S.A. Nursing Council as a midwife;

- it is desirable that the midwife is registered as a general nurse and community nurse in order to render comprehensive care (Reformulate);

- the midwife demonstrates skill and competence with the changing scientific and technological advances in the first stage of labour

- she actively participates in staff development programmes.

- it is desirable that the midwife be an active member of the S.A. Sociery for Midwives (Reformulate).

- The midwife practices within the ethical and legal frame work of:

- the Nursing Act No. 50 of 1978, as amended.

- the S.A. Nursing Council rules and regulations:

- the midwives Scope of practice (S.A Nursing Council R2598, as amended)

- other relevant health legislation.

\section{B.PHILOSOPHY}

The philosophy of midwifery practice states the values and beliefs of the organization which may have an influence on the practice of the midwife. This serves as a guide and explanation for actions taken.

\section{Standard}

There is a written philosophy on care during the first stage of labour.

\section{Criteria}

- The philosophy of care during the first stage of labour is a vailable;

- the philosophy is in line with that of the profession and the controlling bodies:

- the philosophy is updated and takes recent advances and scientific knowledge into consideration;

- the following components are contained within the philosophy of care during the first stage of labour:

- the family preparation component (Reformulate);

- the extent of family involvement (Reformulate)

- the quality of the practice of the miduife:

- the role of the midwife:

- the role of technology;

- the approach to childbirth;

- choices regarding different aspects of the first stage of labour.

\section{C.OBJECTIVES}

Principle

Objectives reflect goal directed care during the first stage of labour based on knowledge, skill and judgement

Standard

The mid wife formulates objectives to meet the level of care agreed upon and ensures that they are met.

Criteria

- Written long and short term objectives are available in the labour ward.

- the objectives are consistent with that of the profession, midwifery service and organization:

- objectives are stated in measurable, behaviourable terms and outcomes.
- objectives are attainable, realistic and allow for evaluation of outcome;

- objectives state the extent of family involvement (Reformulate)

- objectives are consistent with the cultural beliefs and wishes of clients as long as family members are not at risk (Reformulate)

- objectives allow for joint decision-making by health care providers and recipients of care (Reformulate)

\section{POLICIES AND PROCEDURES}

\section{Principle}

Policies and procedures relating to the first stage of labour serve as a guide for the provision of midwifery care consistent with that of the profession, midwifery service and that of the organization.

\section{Standard}

Comprehensive policy statements are formulated and regularly updated to serve as a guide for care during the first stage of labour.

\section{Criteris}

- Policy and procedure manuals are available:

- The Nursing Act No. 50 of 1978, as amended and its regulations;

- Related SA. Nursing Council rules and regulations:

- The most recent promulgated Acts and regulations pertaining to the practice of midwifery:

- Written midwifery care policies are a vailable and include the following

- Admission and preparation of patient:

- Parameters and methods for ongoing assessment of the intrapartal family (Reformulate)

- Parameters and methods for the progress of labour.

- Parameters and methods of pain relief;

- Parameters and methods for emergency procedures:

- Referral to other disciplines;

- The Client

- Family involvement (Reformulate);

- Support person,

- Prevention of infection 
- Food and fluids;

- Positions;

- Safety;

- Health education (Reformulate)

\section{E.SCIENTIFIC METHOD OF NURSING}

\section{Principle}

The use of the scientific method of midwifery contributes to individualized goal directed quality midwifery care.

\section{Standard}

The scientific method of midwifery is utilized in accordance with the Nursing $A$ ct and scope of practice for midwives (S.A. Nursing Council R1598, as amended).

\section{Criteria}

The principle of scientific midwifery (assessment, planning, intervention and evaluation) are utilized and documented for each intrapartal family from admission to the end of the first stage of labour.

\section{ASSESSMENT}

Principle

The midwife assesses the childbearing family to identify risk factors, educational needs, care needs and referral needs.

\section{Standard}

Each family's needs are assessed in totality by a registered midwife or student midwife under supervision of a registered midwife.

\section{Criteria}

- On admission to confirm the advent of labour,

- Education and preparation;

- Childbirth expectations and goals;

- Continuously to

- determine progress of the first stage of labour

- monitor maternal physical and psychosocial condition

- monitor fetal conditio

- check family need for suppor

\section{PLANNING}

Principle

The midwife establishes a care plan for the childbearing family based on the midwifery diagnosis which includes the specific goals and interventions delineating midwifery actions unique to the family's needs (Reformulate).

\section{Standard}

A registered midwife or student midwife under supervision of a registered midwife is responsible for planning the care of the family (Reformulate).

\section{Criteria}

- Data obtained from assessment form a basis for midwifery diagnosis and contributes to the formulation of a care plan.

- Planning of care is in compliance with:

- the scope of practice for midwives (S.A. Nursing Council R2598, as amended) and its regulations;

- written objectives, policies, procedures and standards of midwifery care during the first stage of labour,

- the needs of the family (Reformulate);

- the medical therapy as prescribed by the medical practitioner,

- the therapy prescribed by other health team members (Reformulate).

- Planning of care is modified as the need arises.

\section{IMPLEMENTATION OF CARE}

\section{Principle}

The midwife implements interventions based on the developed midwifery care plan.

\section{Standard}

Implementation of care is done by registered midwives or student midwives under supervision of a registered midwife.

\section{Criteria}

- Care is facilitative and supportive

- Care is continuous (Reformulate).

\section{EVALUATION}

Standard

Midwives evaluate family responses to midwifery intervention and revise the midwifery diagnosis and the midwifery care plan.

\section{Criteria}

- Evaluation of goals is done continuously and at specified times;

- Evaluation of goals is documented;

- Progress of labour is documented on a partogram

\section{DOCUMENTATION}

Principle

All care rendered is documented on the care plan.

Standard

Documented care reflects the family status (Reformulate)

Criteria

- Documentation is done to:

- evaluate the attainment of objectives;

- indicate midwifery interventions carried out and reflect the family's responses to these interventions (Reformulate);

- meet legal requirements;

- indicate patients' needs, problems capabilities and limitations.

- documentation is done daily and nightly in compliance with written midwifery service policies.

F.QUALITY CARE BY THE MIDWIFE DURING THE FIRST STAGE OF LABOUR

Principle

The midwife facilitates and promotes the maintenance of the health of the family Midwifery care is based on scientific knowledge and available technology (Reformulate)

\section{Standard}

Midwifery care during the first stage of labour is directed towards the safe delivery of a live healthy infant and a fulfilling childbirth experience for the family and the midwife.

\section{Criteris}

- The psychological environment is conducive to a trusting relationship between the midwife and the other health professionals (Reformulate). 
- The midwife creates a positive childbirth experience by:

- unconditional acceptance of the family values and beliefs (Reformulate);

- welcoming the family or support person (Reformulate);

- allowing the family a choice in the type of delivery experience as long as it is not detrimental to the health of the family (Reformulate);

- allowing the partner/support person to be present throughout the first stage of labour if so desired;

- respecting the family's dignity;

- accepting and promoting the family's rights and responsibility to participate actively in decision making (Reformulate);

- providing privacy;

- accepting and respecting the families uniqueness:

- displaying confidence in the execution of her duties

- accepting and promoting the expression of positive and negative foelings;

- displaying communication skills

\section{Standard}

The facilitating function of the midwife consists of guidance, support and accompaniment according to the needs of the client and family.

\section{Criteria}

- Guidance

- guidance is given in the form of suggestions, direction and supervision;

- guidance is given on aspects in which the family lacks knowledge or experience:

\section{- Support}

- support signifies the family will not be left unattended and uncared for during the first stage of labour (Reformulate)

- support will be physical, emotional, spiritual and informative support

Accompaniment

- Standard

Accompaniment will lead to independent decision-making in order to have a worthwhile childbirth experience
Safe environment

- Standard

- The midwife creates a safe environment for the childbearing family by minimizing medico-legal risks:

- The midwife is familiar with the location and use of emergency equipment and procedures;

- The midwife follows the principles of aseptic technique and infection control;

- The midwife is responsible for availability and adequacy of supplies and equipment.

\section{CONCLUSIONS}

The standards submitted for validation were acceptable on the whole. The possible limitations identified were the lack of understanding of the definition of the family and the small number of midwives who have the qualification in community health suggesting that the mother is seen not as part of a family but as an individual entity on her own.

Each group of standards is discussed separately below.

\section{THE MIDWIFE}

The standard and criteria in this group were accepted unchanged except for two criteria which must be reformulated. The one which proves interesting was that only four $(22.2 \%)$ in the quantifying phase have a qualification in Community Health, thus they possibly did not see the need for the midwife to be Community Health trained as indicated by their scoring. The respondents agree on the point of remaining up to date with recent advances, but not by active involvement of the S.A. Society for Midwives. Only four in the group of twenty five did not mark a score of four thus clarity does not exist whether the criteria is impractical or needs reformulation.

\section{PHILOSOPHY}

The standard and its criteria in this group were accepted unchanged except the one involving the family. The mother is not seen as part of a family but rather as an entity on her own A nother possibility is the definition of the family was ambiguous; some interpreted the family as the extended family as indicated in their comments, and others as the nuclear family. Thus the criteria need to be reformulated.

\section{OBJECTIVES}

The standard as well as the criteria regarding the necessity of objectives was unchanged The objectives regarding family involvement have a SD of 0.577 and 0.554 respectively Some respondents had a problem with the definition of the family thus giving a score of two each. The criteria regarding joint decision-making between client and care providers required reformulation because of an $\mathrm{SD}$ of 0.554 . According to the literature this is an essential objective and midwives must be educated regarding its importance.

\section{POLICIES AND PROCEDURES}

The standard and criteria regarding the need for policies and procedures was accepted unchanged except the ones on family involvement which required reformulation due to lack of clarity of the definition. The criteria on health education also need reformulation. Midwives need to be educated about this aspect as health education is a necessity.

\section{THE SCIENTIFIC METHOD OF NURSING}

The standard as well as its criteria on the scientific method of nursing was accepted unchanged.

\section{Assessmen}

The standard and its criteria on assessment were accepted unchanged.

\section{Planning}

The standard as well as three of its criteria were rejected and require reformulation. It is interesting to note that it is once again the ones involving the family due to lack of clarity of the definition of the family. The criteria involving other team members also required reformulation. It appears as if the midwives who rejected this criteria are not ready to plan their care in conjunction with other health professionals and this in fact is a necessity in order to render comprehensive care to the client/family.

\section{Implementation of care}

The standard as well as the criteria on the implementation of care were accepted unchanged except for one which was not completed by seven respondents because the scoring soction was omitted by accident. The rest of the respondents filled it in themselves

\section{Evaluation}

The standards and all their criteria were accepted unchanged

\section{Documentation}

The standard and its criteria were accepted unchanged except the ones involving the family.

\section{QUALITY CARE BY THE MIDWIFE DURING THE FIRST STAGE OF LABOUR}

The standard regarding the family was 
rejected and requires reformulation due to lack of clarity of the definition of the family. The criteria on the other health professionals was rejected because some mid wives are not ready to share the care rendered with other health professionals.

\section{Guidance}

The standard and criteria on guidance were accepted unchanged.

\section{Support}

The standard on support was accepted unchanged but the one criteria needs reformulation because of lack of clarity of the definition of the family.

\section{Accompaniment}

The standard and the criteria on accompaniment were accepted unchanged.

\section{Safe environment}

The standard and the criteria on the safety of the environment were accepted unchanged.

\section{CONCLUSION}

The standards sent in for validation on the whole were accepted, though there were some which needed reformulation. The possible limitations identified were the lack of understanding of the defmition of the family and the limited number of mid wives who have the qualification in community health. The mother is thus not seen as part of a family unit rather as a separate entity.

\section{RECOMMENDATIONS}

\section{FUTURE RESEARCH}

- Reformulation of the relevant standards and criteria.
- Publication of these standards for midwives to use as guidelines for the improvement of the quality of care presently being rendered.

- Development and standardization of an evaluation instrument which is based on these standards and criteria.

\section{IN THE PRACTICAL SITUATION}

- Continuing education and inservice education programmes be implemented on family centered care and comprehensive health care; the researcher found these lacking in the research.

- Midwives in hospitals use these as minimum standards of practice for the improvement of the quality of care being rendered.

- Midwives render care according to the needs of the client/family based on current research.

\section{CONCLUSION}

With the rising costs of health care it is imperative that midwives reach towards excellence in care being rendered based on current research. To strive for the ideal the client/family must be active participants in their own health care. It is time for midwives to look at the client as a member of a family and not as an entity on her own. It must be borne in mind that, that which affects her, affects her family too.

\section{REFERENCES}

DOUGLAS, LM \& BEVIS, EO (1983) Nursing Management and Leadership in action. 4th Edition. St. Louis : CV Mosby Company
JENSEN, MD \& BOBAK, IM (1985) Maternity and Gynaecological care. The Nurse and the Family. 3rd Edition. St. Louis : CV Mosby Company.

JERNIGAN, DK \& YOUNG AP (1983) Standards, Job Descriptions and Performance Evaluation for nursing practice. Norwalk : Appleton Century Crofts.

MULLER, M (1986) : Kwaliteitversekering in ' $n$ Kardio-Torokale Verpleegeenheid. M. Cur. Verhandeling. Universiteit van Suid-Afrika, Pretoria.

MULLER, M (1988) : The New Buzz Word Nursing RSA. May 1988 3(5) 42-45.

MULLER, M (1990) : Gehalteversekering in privaathospitale : 'n verpleegkundige perspektief. Doktorale proefskrif, Randse Afrikaanse Universiteit, Johannesburg.

NOLTE, AGW (1990): Standards for Postnatal care. Unpublished research report. Johannesburg. Rand Afrikaans University
M.CUR. Department of Nursing RAU

AGW Nolte

M.CUR. Professor Nursing RAL 